\title{
Novel approaches such as pharmacogenetics and liquid biopsies in tumor treatment in the era of personalized therapy
}

\author{
Milena Kralickova*, Vaclav Liska, Pavel Pitule, Pavel Soucek \\ From EPMA-World Congress 2013 \\ Brussels, Belgium. 20-21 September 2013
}

\section{Objectives}

Current findings in the biology of tumors and also new tools for genome analysis have opened clinical perspectives in oncology, generally termed as 'personalized medicine'. Pharmacogenomics examines how the benefits and adverse effects of a drug vary among patients in a target population by analyzing genomic profiles of individual patients. Tailored treatment to a given patient presenting with a given tumor is a must in these days. Despite outstanding results in colorectal cancer, lung cancer and melanoma, only a few predictive biomarkers are currently justified in routine clinical practice. Unfortunately so far there is still a gap between the growing number of identified deregulated pathways and their actual implementation as part of clinical routine.

Our current focus is on ATP-binding cassette (ABC) transporters that contribute to development of resistance to anticancer drugs via ATP-dependent drug efflux [1,2]. The associations between the expression of $\mathrm{ABC}$ transporters and outcome of carcinoma patients, e. g. breast carcinoma patients, could elucidate some question in pathophysiology of the disease and contribute to new treatment strategies [3].

As long as endometriosis, characterized by the presence of endometrial tissue outside of the uterine cavity, is one of the most common gynecologic disorders in women of reproductive age and has many similarities with cancer, we focus on this disease as well. Endometriosis is an inflammatory, estrogen-dependent condition associated with pelvic pain and infertility. Decreased quality of life is the most important predictor of direct health care and total costs [4]. New interdisciplinary research proposals in the field of endometriosis research will contribute to its better understanding, earlier diagnosis and personalized treatment.

Another issue of our research is the oncofertility. As long as chemotherapeutics, radiation, and surgery can impact the future fertility of men, women, and children with cancer the fertility impairment and loss due to cancer or its treatment is a significant survivorship consideration.

\section{Suggested technologic approaches}

Systems biology approaches are the must for an easier implementation of personalized medicine at the bedside. The new Biomedical centre of the Faculty of Medicine in Pilsen is part of the Charles University. It houses a multidisciplinary team of researchers engaged in collaborative research with partners across the globe. One of the primary focuses of the centre is the identification of predictive biomarkers of drug safety and efficacy with the aim of translation from 'bench-to-bedside'. The Centre is in a close vicinity of the University Hospital in Pilsen and emphasis the education of not only medical students but also clinicians and scientists.

\section{Expected impact if the project will succeed}

New personalized medicine biomarkers, both prognostic and predictive, will contribute to better classification of patients into subgroups for treatment recommendation and also to new personalized treatment of cancer and endometriosis. Our aim is to support our young patients and children also from the oncofertility point of view and to save them hope for future fertility. 


\section{References}

1. Hlaváč V, Brynychová V, Václavíková R, Ehrlichová M, Vrána D, Pecha V, Koževnikovová R, Trnková M, Gatěk J, Kopperová D, Gut I, Souček P: The expression profile of ATP-binding cassette transporter genes in breast carcinoma. Pharmacogenomics 2013, 14:515-529.

2. Brynychová V, Hlaváč $V$, Ehrlichová $M$, Václavíková $R$, Pecha $V$, Trnková $M$, Wald M, Mrhalová M, Kubáčková K, Pikus T, Kodet R, Kovár J, Souček P: Importance of transcript levels of caspase- 2 isoforms $\mathrm{S}$ and $\mathrm{L}$ for breast carcinoma progression. Future Oncol 2013, 9:427-438.

3. Mohelnikova-Duchonova B, Brynychova V, Oliverius M, Honsova E, Kala Z, Muckova K, Soucek P: Differences in transcript levels of ABC transporters between pancreatic adenocarcinoma and nonneoplastic tissues. Pancreas 2013, 42:707-716.

4. Rogers PA, D'Hooghe TM, Fazleabas A, Giudice LC, Montgomery GW, Petraglia F, Taylor RN: Defining future directions for endometriosis research: workshop report from the 2011 world congress of endometriosis in Montpellier, France. Reprod Sci 2013, 20:483-499.

doi:10.1186/1878-5085-5-S1-A33

Cite this article as: Kralickova et al:: Novel approaches such as

pharmacogenetics and liquid biopsies in tumor treatment in the era of personalized therapy. EPMA Journal 2014 5(Suppl 1):A33.

\section{Submit your next manuscript to BioMed Central} and take full advantage of:

- Convenient online submission

- Thorough peer review

- No space constraints or color figure charges

- Immediate publication on acceptance

- Inclusion in PubMed, CAS, Scopus and Google Scholar

- Research which is freely available for redistribution

Submit your manuscript at www.biomedcentral.com/submit
C Biomed Central 